Small Business in Russia: A Case Study of St. Petersburg

\author{
By: Alessandro Kihlgren
}

William Davidson Working Paper Number 439

January 2002 


\title{
Small Business in Russia: A Case Study of St. Petersburg
}

\author{
Dr Alessandro Kihlgren \\ Post-Doctoral Research Fellow the Division of Economics and Enterprise, Glasgow Caledonian \\ University, 70 Cowcaddens Road, Glasgow G4 OBA. \\ Email: A.Kihlgren@gcal.ac.uk/sylvande@comm2000.it \\ Phone number: 0141-331 8948 Fax: 0141-331 3293
}

\begin{abstract}
:
The reasons why small business development has been disappointing in Russia compared with other transition countries such as Poland and the Czech Republic are here analyzed. It is, however, suggested that the picture may not be so gloomy as official statistics suggest. As far as St. Petersburg is concerned, it has witnessed an exceptional - by Russian standards - growth in this sector in the 1990s, although it still trails compared with Moscow. This, despite the lack of support from the local administration and despite having an income per capita close to the Russian average. Again official data may be at fault through undervaluing the importance of the small business sector in the early 1990s.
\end{abstract}

Keywords: small business, entrepreneurship, Russia, St. Petersburg, statistics 


\section{Non-technical summary}

The paper is about the development of small business in Russia with a focus on St. Petersburg. When analyzing small business it is necessary to take into consideration that the limitations in the Russian definition of small business make the figures not fully comparable with those from other countries. The contribution of this sector is, therefore, understated. Moreover, any analysis on this sector is hindered by questions over the reliability of the official data. Therefore, we can not take for granted that the apparent stagnation in the small business sector is a real occurrence, considering the persistent growth of registered businesses which by 1999 were three and half times as many as the number of small businesses (the figures provided by Goskomstat regarding the total number of small firms refer only to active enterprises). Is the difference entirely attributable to non-active firms or is Goskomstat (the official statistical body) under-estimating this sector? A clue indicating a possible under-estimation comes from a survey carried out by Clarke and Kabalina, which points to a continuous growth of the new private sector share of total employment in the 1990s. It is, however, clear that in Russia the growth of small business has been slower compared with the leading transition countries (Poland, the Czech Republic and Hungary). In Poland, and to a lesser degree in the Czech Republic, this sector has been the engine of the economic recovery. A natural question is why Russia differs. Apart from the fact that in contrast to these countries Russia does not have an entrepreneurial tradition and has experienced communist rule longer what is especially distinctive about Russia has been the strong influence of interest groups during the transition process which favored the allocation of entrepreneurship to largely unproductive activities. The following factors which have stifled small business creation and resulted in a very high failure rate can in part be attributed to the above-mentioned phenomenon: the business-unfriendly legislative framework characterized by the lack of clear rules; the income inequality; the high level of corruption and crime; the unpredictable economic environment; the scarcity of financing and the precarious state of large industrial firms.

By Russian standards, St. Petersburg has experienced a exceptional growth in the small business sector, even if its level is still below Moscow. However, it may be presumed that data referring to the early 1990s underestimates the contribution of small business in St. 
Petersburg, especially regarding retail trade and public catering firms. The expansion has taken place despite the fact that the business environment in St. Petersburg does not differ from that in Russia in general and income per capita is close to the Russian average. This is in contrast to Moscow where the expansion of small businesses can be ascribed to much higher income levels and to the active promotion of the local administration. In St. Petersburg the local administration has not been particularly business-friendly, dispensing favors to its "cronies" and doing little to rein in bureaucratic abuses. Policy making in industry has been centered, in particular, on helping certain sectors deemed as priorities, but the efficacy of these measures is doubtful at best. Economic policies in St. Petersburg may be seen as being shaped by the mentality of a planned economy, reflected in the drafting of countless plans and measures, which have, however, largely remained unrealized. Little has, instead, been done to meet the demands of small businesses. In trying to explain why small business has performed so well in St. Petersburg a few reasons can be suggested. The higher educational level compared with Russia as a whole and the "Western mentality" of the population has represented a fertile environment for the emergence of entrepreneurship. The expansion of the small business sector has been boosted by the much larger retail spending per head than in Russia as a whole due a variety of factors (the presence of a relatively large middle class - by Russian standards - the comparatively large foreign community and the tourist industry). This explains why growth has been particularly strong in the service sector. On the contrary, despite the wealth of scientific knowledge in the city, scientific firms have not developed to any great extent. 


\section{Introduction}

Small business in Russia has not fulfilled expectations, either in the late Soviet period or since the communist downfall. Legalized in the second half of the eighties when the Soviet Union was still in place to improve the availability of goods which were in short supply, it was initially expected to function within a system which was to remain largely planned. Instead, it might have exacerbated the scarcity of these goods and, by making the internal contradictions more evident, accelerated the fall of socialism. Similarly, the economic transition in Russia has been characterized by the limited development of small business which has been particularly disappointing when compared with the leading transition countries, especially Poland and the Czech Republic. Poland had 2,000,000 small firms in $1997^{1}$. The newly established private sector has been the main force behind the economic recovery and has led to a strong growth in the manufacturing sector in Poland (although growth has been slower than in services). By the late nineties, SMEs accounted for two-third of GDP and more than half of manufacturing output according to Gomulka² (Meth-Cohn, 1999), Even in the Czech Republic, growth has been strongest in small industrial firms, while the contribution of large industrial enterprises has decreased (Borish and Noel, 1996). The share of the former in total industrial production has increased from 3.8\% in 1991 to 22.6\% in 1997 (Bohata and Mladek, 1998). The evidence from Hungary suggests that the industrial restructuring can be largely ascribed to foreign investment. However, small business accounted for 30-35\% of GDP as early as 1994 and its share of the economy was on the increase (The Delegation of Hungary, 1996). The growth in small business in these countries seems to have been an organic process, once economic deregulation had been conceded, as policy making has devoted little attention to the emergence of entrepreneurship despite the key role it was supposed to play in the economic transition. A natural question, therefore, is why Russia differs.

\footnotetext{
${ }^{1}$ The definition of small firm is not, however, uniform across all the transition countries. Statistical bodies in Poland define a small firm as having fewer than six employees and a medium-scale firm as one with 6-50 employees, so the terms small and medium firms broadly correspond to the Russian definition of small firms. Poland's figure probably refers to small and medium-sized companies, as defined by Polish statistical bodies.

${ }^{2}$ Gomulka is a well known economist who has also served as an advisor to the Polish Finance Ministry.
} 
I have chosen to focus in particular on St. Petersburg because it seemed to be one of the most appropriate places where small business could progress in Russia. St. Petersburg represents the most European part of Russia with a highly-educated population. It is a leading industrial center with a high share of high-technology industries, most of which formerly belonged to the military industrial complex. Several international programs to promote entrepreneurship have been established in St. Petersburg. It is also one of the most liberal cities in Russia, having always returned pro-reform majorities since the first free elections in the early nineties. Even in Soviet times the city had a tradition of being strongly reformist and tried to follow its own path of development. Since the 1950s specific programs were devised by local authorities to foster innovation in industry. For these reasons it is reasonable to expect that economic reforms would take root more easily in St. Petersburg compared with the rest of the Russian Federation, and consequently create a favorable environment for the development of entrepreneurship.

Qualitative in-depth interviews were conducted in order to obtain a first-hand account of the business environment within which small businesses operate. The fieldwork was conducted in the period August 1997-October 1998. In total, more than 40 people were interviewed, of which seven were entrepreneurs and the rest were representatives of entrepreneurial associations, foreign firms, research institutes, the Academy of Science, foreign and Russian organisations promoting small business and also university professors and members of the local administration. Not all are reported in the study, but nevertheless most provided useful feedback. All entrepreneurs but one were involved in manufacturing. This was a deliberate choice because it is the development of manufacturing firms which plays the most important role for economic growth. The multiplier benefits of an expansion in the manufacturing sector are likely to be greater than those of a similar growth in service sector activity (Fothergill and Gudgin, 1982; Smallbone and other, 1997). Dertouzoz, Lester and Solow (1989) argue that despite the obvious transformation of economic activity from manufacturing into services, manufacturing remains the cornerstone of a modern industrial economy.

\section{Factors which have led to a slower development of small business in Russia compared to the leading transition countries: an analysis}


Mainstream small business theory can be of only partial help given the particular conditions of the transition from a planned to a market economy. Entrepreneurs' personalities in Russia have been found to be quite similar to those in advanced market economies (Ageev, Gratchev and Hisrich, 1995; Kuznetsov McDonald and Kuznetsova, 2000) and the system of cultural values, which came into being in the last decade, is very sympathetic to entrepreneurship. Sociological studies have shown a rather positive attitude of the population towards private enterprises (Kuczi and Lengyei, 1995; Radaev, 1993; Blinov, 1998). Shiller, Boyko and Korobov (1991) found Russians favorably inclined towards markets, in similar proportions to the populations of the United States, Germany and Japan. Research has shown that an abrupt shift in values has taken place since the beginning of perestroika. This has resulted in entrepreneurship being considered highly prestigious. The main reasons for the poor development in Russia put forward in this paper are the following:

- $\quad$ historical reasons which contributes to the lack of entrepreneurial culture

- Olson's theory about the existence of strong interest groups which shares common ground with Baumol's theory on relative rewards for different types of economic activity.

The first explanation suggests that Russian entrepreneurs have less experience than their Eastern counterparts and therefore less developed business skills. This is because, unlike Russia, there was in the leading transition countries a strong entrepreneurial sector before the communist take-over, because communism lasted for slightly more than forty years instead of more than seventy and because domestic firms had more interrelations with Western counterparts. In addition, in two of these countries (Poland and Hungary) some entrepreneurial activity was allowed. The result is that key business skills are alien to Russian entrepreneurs and it will take a while before they are able to acquire these. Russian entrepreneurs may be highly qualified, but feel themselves lacking proper management and business knowledge (Babaeva and Lapina, 1997). For this reason, even if the new favorable attitudes to entrepreneurship have encouraged the creation of new firms, failure rates have been extremely high. 
Olson's (1982) contention that the existence of strong special interest groups in a country limits its ability to adopt new technologies and reallocate resources as a result of changing conditions is particularly relevant in Russia where the strong power of interest groups has led to the concession of extremely favorable conditions for well-connected individuals and has strongly influenced economic policy. This contrasts starkly with the leading transition countries, where the political leadership has been largely replaced, domestic policy has been less dominated by vested interests and "rules of the game" have been more clear and more fair. As a result of this, the relative rewards for different types of economic activity have favored the allocation of entrepreneurship to largely unproductive activities, such as rent seeking and organized crime, rather than to productive activities.

The phenomena described above can, to a greater or lesser extent, be identified as having given rise to the following six conditions, which have had a much greater impact in Russia, than in the leading transition countries, and have acted as a constraint to small business development:

1. high levels of corruption

2. strong income inequality

3. a business-unfriendly legislative framework and the general situation of instability caused by the lack of clear rules

4. the scarcity of financing for small businesses

5. the precarious state of large industrial enterprises

6. a high level of crime.

1. Corruption is one of the main factors indicated by the entrepreneurial class which adversely affects their activity. Russia has become one of the most corrupt countries in the world in the nineties. It came 47th out of fifty-four countries analyzed by the University of Gottingen (Business Eastern Europe, 1996). Similar conclusions have been reached by the Economist Intelligence Unit and by the DRI/McGraw Hill Risk Service (EBRD, 1997). This phenomenon was not so acute in the 1980s, when its incidence was lower than in some East European countries (Business Eastern Europe, 1996). As the higher echelons of power have been guilty of one form of corruption or another in the eyes of the population and asset grabbing has been going on practically 
unchecked, the behavior of those in power has been replicated by lower levels of the bureaucratic structure. The poor salaries of state employees has also acted as a moral justification for their behavior.

2. Income inequality has passed from being very moderate at the beginning of the decade to becoming one of the highest in the world while the variation has not been substantial in countries such Poland, Hungary and the Czech Republic (Milanovic, 1998). The large increase in income inequality has been particularly damaging because the new rich have indulged in conspicuous consumption and saved their wealth abroad, without investing in the domestic economy. The existence of a middle class with the financial resources to engage in entrepreneurial activity is still marginal, except in Moscow, St. Petersburg and few other cities. At the same time the poorer classes hardest hit by the transition have been hardly able to afford education, resulting in decreased educational attainment.

3. A complex yet deficient legislative framework is one of the features which has characterized the poorly performing transition countries in relation to the leading transition countries. In Russia the legal framework is characterized by an obstructive regulatory regime, high taxation and conflicting and convoluted legislation. Since taxation takes away about $80 \%$ of a company's profits the entrepreneur is left with no other option than carrying out a significant proportion of a firm's activities in the nonregulated sector. Opening and managing a business is more complicated and subject to greater bureaucratic interference than in Poland (Schleifer, 1997). Comparisons with the Czech Republic and Hungary are likely to be equally unfavorable to Russia. In Russia a clear delimitation of power among the bodies which can enact legislation is lacking. The result is an array of conflicting rules, making it impossible for an entrepreneur to follow the law. The entrepreneur is, therefore, subject to the whims of the supervising bodies. As emphasized by some leading authorities ${ }^{3}$, favored groups

\footnotetext{
${ }^{3}$ Orlov, president of the Academy of Economics, argued that the state policy towards small business is in effect aimed at increasing state revenues and providing financial benefits for state bureaucrats, since the maze of regulations invites bribery (Nelson and Kuzes, 1995). Kivelidi, the director of the Council on Entrepreneurship, an independent think tank established by a Yeltsin decree, asserted that entrepreneurship seemed for the
} 
might have had an interest in avoiding the implementation of a clear legal and tax framework, as their business dealings have been conducted on the fringe of the law and in order to prevent the emergence of new economic actors who could challenge their dominance, but no conclusive evidence can be provided on this point. It might also be argued that this is the result of the fact that historically there has been little respect for the rule of law in Russia. Whatever the reason, probably a combination of these two factors, after almost a decade, legislation seems to serve the purpose of discouraging business, rather than providing a framework in which it can prosper. The Russian tax system favors consumption over investment, being particularly punitive on manufacturing activities, and is therefore a serious impediment to growth. Simplification of taxation had been on the agenda for many years, but it was only with the enactment of the first and the second part of the new tax code in 1999 and 2000 that it was partially achieved.

4. Financing for small business has been extremely scarce. The banking sector is much smaller than in the leading transition countries and a very high proportion of domestic credit goes to the government and public enterprises (Russian Economic Trends, October 1997). Banks have been very cautious in financing small businesses, especially new start-ups which are considered too risky, given their high failure rate. Part of the blame lies with the state policy which encouraged the banks to invest in state bonds, instead of in the real sector. Then, the state-induced collapse of the banking system in 1998 led to a dramatic decrease in the amount of credit going to small businesses. State programs intended to develop small business have also remained largely unfulfilled, fueling doubts as to whether there is a real intention to promote it. Worse still, the limited resources allocated to the Federal Fund for Small Business Support were mostly mis-spent. In total about $90 \%$ of the resources received from the state were not utilized correctly (Sokolovskaia, 1998). It can be concluded that the abolition of the State Committee for the Support and Promotion of Entrepreneurship in late 1998 has, therefore, not been greatly regretted by the entrepreneurial class.

government only "an abstract idea and even dangerous. It is a threat to their existence" (Nelson and Kuzes, 1995). 
5. Because of the larger output decline, industrial enterprises are in a worse condition in Russia than in the leading transition countries. Privatization has not led to a significant restructuring. One reason put forward is that privatization has not brought about a high degree of management turnover, e.g., as in the Czech Republic, thus leaving in place the old management regardless of their business skills. However, the state of industry can not only be attributed to poor skills of managerial staff. Industrial firms in Russia are penalized both by a punitive taxation system and high utility prices, as well as having to survive while receiving less than half of the revenues in non-cash form for most of the 1990s. The payment crisis which has arisen means that in 1997 an enterprise received on average less than $20 \%$ of its sale revenues in cash, rather than in non-monetary forms of payment. The rest was composed of veksels (promissory notes), mutual off-sets and barter operations (Russian Economic Trends, 1998, no. 1). The share of revenues represented by cash has subsequently risen to 35\% in August 1998, 49\% in February 1999 and two-thirds one year later. (Russian Economic Trends, 2000, n. 4; Russian Economic Trends, May 1999; Bofit, 2000). In some cases they are also bankrupted by the opportunistic behavior of the management who strip them of their assets for personal gain or intentionally cause bankruptcy in order to buy the firm cheaply. Adding to all this the depressed level of demand, it is, therefore, very hard for enterprises to prosper. In other East European countries the role of large enterprises has been instrumental in fostering the expansion of small enterprise networks; but in Russia the poor economic condition of most large enterprises has meant that a major sales outlet for small businesses is almost absent. While, for example, in Slovenia many small industrial firms were suppliers of large establishments (Bartlett and Prasnikar, 1995), this option was scarcely available in Russia.

6. The payment of protection money is more widespread in Russia than in Poland or the Czech Republic (Shleifer, 1997), but the constraint that racketeering evidently places on business activity has not been ranked among the foremost of problems identified by entrepreneurs (Chepurenko, Avilova and Pripisnov, 1995; Radaev and others, 1995; Voprosy Statistiki, 1995; Leontief Center, 1998). One reason for this may be a 
reluctance to discuss protection rackets, which makes any assessment of their effects difficult, but studies have generally considered the effects of racketeering a less pressing difficulty than those associated with complying with complex and contradictory legislation (Babaeva and Lapina, 1997; Zhuravskaya, 1998; Blinov, 1996).

The absence of supporting networks is another reason which can be adduced for the slow growth of small businesses in Russia, although on this point we do not have enough evidence to confirm that the situation is worse than in the leading transition countries. The importance of networks is well documented in the economic literature (Brunner, 1993; Porter, 1990). In Russia, given the economic turmoil and the underdevelopment of market institutions, networks are likely to play an even greater role, a fact which has been highlighted by several studies (Kuznetsov McDonald and Kuznetsova, 2000; Neace, 1999). These networks facilitate high trust relationships, thereby cutting transaction costs. However up to now, formal networks have played a very limited role in fostering entrepreneurship in Russia as banks tend to ignore new firms, consulting is mostly unaffordable and business associations reach a limited number of entrepreneurs. According to a research carried out by the Leontief Center (1999), 94\% of entrepreneurs are not members of any association. Informal networks are also poorly developed. The average entrepreneur tends to be isolated ${ }^{4}$. The most relevant network is formed by the former communist nomenklatura, which is the group largely reaping the benefits of transition, while for new entrepreneurs with few connections building a network of trusted partners will take time as trust usually evolves slowly.

\section{Statistical analysis of small business development}

Assessing the level of development of small business in St. Petersburg and in Russia as a whole requires a critical analysis of official statistics, due to the existence of several inconsistencies. In the opinion of the Institute for Private Sector Development and Strategic

\footnotetext{
${ }^{4}$ Webster and Charap (1993) found in 1992 that entrepreneurs in St. Petersburg tended to be isolated from each other, from the state sector and from the outside world. This fact has also been emphasized by Pechatnikov, the director of a Business Development Center, in a recent article in a St. Petersburg newspaper (Belenkova, 1999).
} 
Analysis (IPSSA, 1997), one of the major research centers on small business in Russia, the current statistical methods give only an approximate indication of the trend of small business development, rather than the true size of this sector. Statistical data are sometimes controversial and the method of recalculation used is not clear. Goskomstat's statisticians themselves admit that the system of collecting and analyzing statistical data does not allow them to follow with due precision developments in the private sector of the Russian economy (Alimova and others, 1998). On occasion national and regional offices of Goskomstat have provided two different sets of data on small business in the same region, as data sent to the headquarters in Moscow are recalculated using their own methods. For example, in the Tomsk region the number of small enterprises was estimated to be 4,356 in October 1995 by the regional branch of Goskomstat, while the official statistics of the Russian Federation indicate figures of 5,673 and 5,176 in June and December 1995 respectively (Radaev, 1997). The difference of $15-25 \%$, depending on the month referred to, is quite significant. In addition, the frequent changes in the methodology make it difficult to compare the data across the period. The small business share of total employment was only $13 \%$ in $1999^{5}$ in Russia, compared to an SME share of two-thirds in the EU (OECD, 2000; Russian SME Resource Center, 2000). It must be taken into account that Russian and Western official data on small business are not fully comparable, as the Russian definition of small business has several limitations ${ }^{6}$. For this reason the contribution of this sector to the economy is understated. A question mark hangs over the apparent stagnation of the number of small businesses since 1994, considering the continuous growth of registered enterprises (the figures provided by Goskomstat regarding the total number of small firms refer only to active enterprises). Is this only an effect of the non-liquidation of inactive enterprises or is Goskomstat underestimating their numbers? Unfortunately there is very little evidence on this point.

\footnotetext{
${ }^{5}$ Yearly figures as of $31^{\text {st }}$ December.

6 The definitions stated in the state program approved in 1995 are:

- the share of charter capital belonging to legal entities which are not small businesses, to state, religious, social and charitable organizations and other foundations must be lower than $25 \%$ (previously there was no limit concerning statutory capital).

- a maximum of 100 employees in industry, transport and construction (previously 200 by law), 60 in science, scientific services and agriculture (previously 100), 50 in wholesale trade, 30 in retail trade/public catering and consumer services (previously 15) and 50 in other spheres of activity (previously 50 for other sectors of
} 
In contrast to official statistics other sources give a much more positive picture of this sector. Babaeva and Lapina (1997) estimate the total number of small business employees at twenty million in 1995, that is to say one-third of the labor force, including those who are officially employed in state firms or unemployed, but who are really engaged in small business activity instead. According to data from a survey carried out in five Russian cities, the share of new private firms in total employment was $18.4 \%$ in 1998 , or $20.6 \%$, including secondary employment, which is mostly unregistered. Also adding self-employment it would be $22.5 \%$ (Clarke and Kabalina, 1999). They found this share to have posted a continuous growth since 1987. What is puzzling is that growth became steadier after 1994 when officially the small business sector stopped growing. According to their data the majority of people employed by these new enterprises are employed by firms which fit the definition of small businesses. So, there are reasons to believe that that the small business contribution has not been fully captured in official statistics.

Although there are no official data on survival rates, small businesses in Russia seem to be characterized by an extremely short life-span (Holtmann, 1997; Polonsky, 1998). Many firms were created in the enthusiasm of the new opportunities arising from the transformation of the economic system, but often lacked a clear market analysis and therefore could not survive long. The low output per firm - slightly more than $\$ 6,000$ per year in 1997 (Russian SME Resource Centre, 1998) - testifies to the low development stage reached by most firms. Even taking into account the fact that Goskomstat does not capture the grey economy in its figures surveys and experts' estimates suggest that this is around $30-40 \%$ in the small business sector (studies reported by IPSSA, 1998), the picture does not change substantially. A critical aspect of small business support is, therefore, not only to increase creation rates, but also to assist existing firms to survive and prosper. Conflicting survey results do not give a clear indication as to how small businesses are faring, but the prevalent picture has not been very favorable for industrial firms, while for trading firms the picture is mixed (OECD, 1997; Avilova and others, 1997; Vasil'chuk, 1997; Deikin, 1998). However, the rouble devaluation of August 1998 has altered the picture in some industrial sectors. Output in small industrial enterprises increased by $61.8 \%$ in the course of 1999 as domestic producers have benefited from the steep 
price increase in foreign goods and from a change in the population's perception of domestic goods (Alimova and Ermilova, 2000).

\section{How small business is faring in St. Petersburg}

The majority of the firms covered in the interviews (all industrial firms, but one) ${ }^{7}$ remain in a very precarious financial position. They do not generate enough circulating capital to make any investment and have to utilise old and outdated equipment. Nor can they earmark enough financial resources to advertise their products, while often having to compete with foreign firms which can afford a much larger advertising budget. No figures were given as to profitability, but all complained that production is hardly profitable. However, Russian entrepreneurs might exaggerate their economic plight because they want to attract as little attention as possible. They tend to be very secretive when asked about these kinds of data. From these interviews it seems that the better-performing firms are those selling directly to consumers or retail outlets, while those selling to industries or budget-financed institutions have great difficulties surviving. However, even for the former, the limited purchasing power of the population acts as a major stumbling block to their expansion. Among the entrepreneurs there is a palpable resentment towards Moscow, which in their opinion enjoys a much higher standard of living at the expense of the rest of Russia. A constant remark is that $70-80 \%$ of the financial resources of the country are concentrated in Moscow ${ }^{8}$.

The interviews carried out have highlighted how the success of a business is connected to a variety of factors which make the business environment unpredictable. One firm (BMN) is resigned to having lost a substantial amount of money because a major bank of St. Petersburg,

${ }^{7}$ Interviews were carried out with:

- T. B., general director of Fitolon, a pharmaceutical company created in 1992.

- E. C., general director of Melp, a firm created in 1993 which produces medical equipment.

- S. H., general manager of Slavia, a publishing house, set up in October 1990.

- O.L., general director of Acvasviaz, a company set up in 1991 which develops and produces anti-theft devices and anti-fire equipment.

- M. M., general director of Gefest, a furniture producing firm created in 1988.

- T. P., director of BMN Peterburg, an advertising agency created in 1992.

- E. R., chief accountant of R. (the interviewee requested the name of the firm not be published), a firm set up in 1991 to develop and produce remote-controlled mechanical systems for x-ray and optical applications.

${ }^{8}$ Confirmation of this can be found also in academic literature (Pimoshenko 1996: 54). 
one of its clients, on behalf of which it had anticipated the payment of advertising, found itself in financial difficulties and is unlikely to pay back the debt ${ }^{9}$, another firm (Acvasviaz) was almost bankrupted at the beginning of its activity because a state institution could not pay for what it had ordered, not having received the funds from the budget, the market niche targeted by a third company (Melp) disappeared in 1995-1996 after a few years of work because industrial clients no longer had the resources to spend on the ecological treatment of water and, according to the company's director, resorted to throwing water away without cleaning it, despite this being illegal. For this reason this firm turned to the production of medical equipment. The problem of the lack of compliance with the law also seriously affects Acvasviaz which has a potentially large market, as the installation of anti-fire equipment is compulsory. However, few firms can currently afford to abide by the law, since most Russian industries are in a very bad economic condition, and for this reason resort to bribing inspectors rather than complying with the regulations.

Because of the considerable swings in the level of market demand and the unpredictability of the environment firms tend to have a very flexible employment structure. Staff is usually reduced to a minimum, usually just administrative personnel, while industrial workers are employed only where there is an order. Alternatively, the work is contracted out to a larger factory where, usually, the problem is the converse: a surplus of workers. Other major problems encountered by these entrepreneurs are the continuous inspection by the tax and other departments, which can block a firm's activity; the freezing of a firm's bank account by tax bodies without warning; fraud, against which legislation offers little protection; a tax burden which makes non-compliance a necessity in order to survive; the onerous accounting procedures; the difficulties in obtaining outside financing; the lack of an effective patent law which can be enforced against imitators, the lack of domestic suppliers capable of meeting their requirements and in some cases the perceived inferiority of Russian products by the population. It seems that Russian consumers, who used to have a very low opinion of domestic products, now have a higher regard for domestic goods, which are not necessarily thought worse than foreign equivalents, according to a recent survey carried out by the Stockholm School of Economics in St. Petersburg (Shcherbakova, 1999: 9). In sophisticated goods such

\footnotetext{
${ }^{9}$ This happened before the financial crisis of August 1998.
} 
as household appliances, a Russian brand can, however, still be an handicap, as also indicated in the same survey ${ }^{10}$. The penetration of foreign products reached its peak in 1995 when, according to official data, they accounted for 54\% (Russian Economic Trends, 1999, no.1) of retail sales. Since then, a counter trend has developed so that by the year 2000 foreign goods accounted for only 34\% of retail sales (Russian Economic Trends, 2000, no. 4).

\section{Economic policy in St. Petersburg}

St. Petersburg has experienced the problems typical of defence-related cities. Few of the major military factories have been able to restructure and re-orient production and this has not been helped by the chaotic state policy towards conversion. The industrial sector in the city witnessed an output drop which was more marked than in Russia in general until 1996. However, from 1997 the situation has been reversed, indicating that restructuring is taking place, at least in some sectors. A common feature of the years 1992-1996 is that regions producing more sophisticated outputs were in a more vulnerable position. The highest rates of decline were recorded in the central (including Moscow) and north-west regions (including St. Petersburg), which are the most developed parts of Russia, while West and East Siberia, regions abundant in natural resources, have suffered much less from de-industrialization. New strategies for the future of the city had, therefore, to be devised in the 1990s as the city lost its importance as a defence center, raising fears of a progressive de-industrialization. In the early 1990 s, the transformation of St. Petersburg into a free economic zone with favorable terms for foreign investors was expected to lead to an influx of foreign investment. It was hoped, that the city would revert to its pre-revolutionary role as a center of international business and finance. However, this project, including the concession of tax and customs advantages, failed to bring the expected results, and the FEZ strategy was applied only to certain areas. Sobchak, mayor from 1991 to 1996, remained committed to the aim of making St. Petersburg an international center of business and finance, but the actual results have fallen far short of expectations.

\footnotetext{
${ }^{10}$ The Stockholm School of Economics has a branch in St. Petersburg.
} 
In view of the disappointing flow of foreign investment, the new mayor has paid much less attention to it, and has declared his main objective to be the restructuring of the industrial sector. A Strategic Plan has been devised to set the long-term strategy for the city economy. However, the Plan seems to be a collection of differing interest-group recommendations without a clear structure and with no apparent strategy for the realization of its aims. A common feature of the post-transition years has been the countless plans devised by city officials. In the end, however, few of the measures indicated in these plans have been carried out. They can be considered more declarations of intent than practical policies. A command economy mentality still seems to be prevalent among economic policy makers, but this is also the consequence of the disastrous situation in which industry finds itself: this situation acts as justification for their involvement. Active involvement to assist the industrial sector is not just a characteristic of the local administration of the city, but of most local administrations in Russia. Given the precarious situation of most industrial enterprises and the social cost of the unemployment that could result from their closure compels the local administration to listen to the cry for help of industrial managers. The actual measures implemented for the industrial sector in St. Petersburg have been the concession of subsidies to specific businesses, primarily in the forms of tax deferments and soft loans, and the reduction of tax rates for specific activities. The criteria for the concession of these have, however, not always been clear, and nor have the positive results, if any, of this policy. The reason for the improved performance of some sectors does not seem to lie with the help they received from the local administration, but rather as a result of other factors such as foreign investment and a change in the tastes of Russian consumers. The last program devised by Klebanov ${ }^{11}$ is more concrete, linking the concession of subsidies to restructuring plans which are based on reducing a firms' size to make it more compatible with actual production levels. One of the main features of this program is the spinning off of small companies from large enterprises. Experience from the Czech Republic shows that the performance of the parent enterprise is generally enhanced once non-essential units have been spun off (EBRD, 1998), but as far as St. Petersburg is concerned the past results of this process have been mixed. So far this program has been applied to only four enterprises and the results have fallen short of expectations. The administration of St.

\footnotetext{
${ }^{11}$ Klebanov was the director of the Committee for Economy and Industrial Policy of St. Petersburg from December 1997 to June 1999. He was subsequently called to serve in the Russian government.
} 
Petersburg has also retained a significant role in promoting co-operation with other members of the Federation, signing agreements to exchange locally-made products for the produce of other regions in order to assure the city an adequate food supply as market signals are still not working properly.

Favoritism has been rife. Despite St. Petersburg being considered a liberal city, mayors have behaved like dictators, trying to subdue the legislative assembly and dispensing favors to their "cronies". Entrepreneurs with the right connections have been able to secure more advantageous conditions in the forms of: premises at knocked-down prices, either on rent or through privatization; city orders; tax deferments; and exemption from inspection. The new mayor, Yakovlev, elected in 1996 promised to put finances in order and cut down on favoritism. In effect, fiscal management has made huge steps forward. The dramatic situation in which the city administration found itself in the early nineties, when the decline in budget revenues due to the severe economic crisis was accompanied by a widening of the responsibilities that the city had to take on, was finally overcome in the late nineties with a balancing of expenditures and revenues. Even if past deficits have left a large debt, St. Petersburg was one of the few Russian cities not to default on the repayments of the loans granted by foreign bodies. Success in fiscal management has, however, not meant that old methods have been eradicated. Municipal tenders are still assigned without proper competition and the strong influence of shadowy figures in local government prompted the architect of financial stabilization to resign in 1999.

\section{Small business growth in St. Petersburg}

Despite the economic problems and the fact that the "rules of the game" have not been equal for all, St. Petersburg has, nevertheless, experienced a very large growth (by Russian standards) of the small business sector since 1992. Even though its level remains lower than in Moscow, the growth in the 1990s has been the largest in Russia. Small business development in Russia has been primarily centered in these two cities, where the economic resources to sustain small business activity are mainly concentrated. The share of small business in total employment in St. Petersburg was 30.4\% in 1999 (taking into account permanent full-time 
workers and contract workers). As a comparison, in Moscow the analogous percentage was 34.8\% (Goskomstat, 2000). The much lower unemployment rate in St. Petersburg compared with Russia as a whole can be in part attributed to the high level of development achieved by this sector in the city. Official unemployment was $1.2 \%$ in March 1998. This is 2.3 times lower than the analogous figure for the whole of Russia ${ }^{12}$ (The Socio-Economic Situation in St. Petersburg. A General Overview, 1998, no. 32).

The engine of this growth has been retail trade and public catering firms, which had only a minor role at the start of the decade. This is in contrast to that of scientific firms, the role of which in the small business sector has progressively waned. In St. Petersburg, the number of small businesses grew by more than 11 times between 1992 and 1999, while in Russia the increase was a mere $60 \%$ and threefold if we consider also the previous year (1991). However, data for 1992 are probably underestimated. In 1992 St. Petersburg accounted for just 1.7\% of all small enterprises in Russia with 3.3\% of the Russian population, while in 1999 the corresponding share was $12 \%$. Such a low level in 1992 is clearly absurd as small business is bound to be more developed in big cities and there is no objective reason why small business should lag so far behind in St. Petersburg in 1992. What is especially puzzling is the extremely low number of retail trade and public catering firms, considering the fact that in 1990 retail trade per capita was almost 30\% higher then in the country as a whole (Goskomstat, 1999). Their concentration in relation to the population was one-fifth of the Russian average in 1992 , but by 1999 it was four times bigger. Different privatization policies cannot explain this as small privatized firms represent a negligible percentage of the whole number of firms. The total number of firms privatized in the city amounted to 3,962 between 1992 and 1996.

This growth has taken place in the absence of a clear policy by the local government to promote small business. In Russia, the attitude towards small business has varied greatly between different local administrations. These administrations have a strong influence on the

\footnotetext{
${ }^{12}$ However, one must bear in mind that a great number of workers made redundant do not bother to register as unemployed because unemployment benefits are extremely low and, therefore, are not included in the statistics. Official figures fail also to take into consideration the number of workers who are employed, but are on forced vacations, and those on reduced working time. According to the rules of the International Labour Organization
} 
business environment: a substantial share of the tax burden is determined by local bodies, as well as the rent of premises, the majority of which they own. They also have considerable autonomy in implementing regulations. In general, the entrepreneurs interviewed in St. Petersburg have been strongly critical of the local administration. The environment is not considered to be particularly business-friendly, and almost all the interviewees agree that it has not improved during recent years. The administration is in particular accused of approving legislation without exercising the proper competence. The entrepreneurs have, instead, a high opinion of the Moscow administration. The resolution of the second congress of the entrepreneurs of St. Petersburg in November 1997 also severely criticized the local administration (Predprinimatel' Peterburga, 1997, no.23). In St. Petersburg financing for support measures has been limited and the little financing provided has been usually mismanaged (Predprinimatel' Peterburga, 1999, no.13; Shabalina, 1999). Small businesses in St. Petersburg do not have political power and have been, therefore, largely ignored by the local government until very recently. Only one business association can boast more than 1,000 members. In more recent times, however, the development of this sector has made it impossible for the mayor to ignore it. The mayor, after failing to attend the second congress of the Entrepreneurs of St. Petersburg, appeared at the third congress in October 1999, pointing to the vast increase in resources earmarked for the small business program for 1998-2000 as proof of the dedication of the current administration to the sector. The program, however, was approved by the legislative assembly only in May 2000 and only for that year and the planned allocations were reduced by about two-thirds. As usual in the general economic policy of the city, various committees have been set up to advise the government and a lot of different measures have been proposed, but most have not yet been applied and the specific legislation approved in the city has had scarce effect. No concrete effort has been made to ease the main problems affecting small businesses in the city (the high cost of premises, the difficulty of obtaining loans, the high level of taxation, bureaucratic racketeering, etc.). The only positive steps have the creation of a single licence chamber, the lowering of the profits tax and the removal of the tax on educational institutions. However, these tax measures alone have had

unemployment was in reality 9.8\% in the city by the end of 1996 (City of Saint Petersburg 1996, 1997). In addition, many workers, although employed, are not paid. 
little effect, as the tax burden remains extremely high. The taxes on total revenues are especially crippling.

In addition to the lack of support from the administration, St. Petersburg, unlike Moscow, does not enjoy a particularly high standard of living, which is only slightly higher than the national average. In 1998 the average income in St. Petersburg was 9\% higher than in Russia as a whole, while in Moscow it was four times as much (Goskomstat, 1999). As these are usually mentioned as the two main factors explaining the expansion of small business in Moscow (especially the higher standard of living), it is reasonable to ask what caused small business to grow so much in St. Petersburg. One question mark hangs over the reliability of these figures, as impressionistic evidence would appear to suggest a substantially higher standard of living in St. Petersburg than in the rest of Russia. Apart from this, the factors which may explain the great expansion of the small business sector in St. Petersburg are mainly:

- The high educational level of the population - the highest in Russia (Lesage and Bayou, 1993 ) - and their more "Western mentality" because of their proximity with advanced market economy, which makes them more prone to engage in entrepreneurial activity.

- The presence of a small, but relevant, by Russian standards, middle class. The population is characterized by a higher than in Russia proportion of pensioners with very low incomes, which means that there is a sizable share of the population with higher than average incomes, who have money to spend on non-essential goods.

- Spending in the city economy is boosted by the presence of a sizable foreign community about 12-15,000 people (Economist Intelligence Unit, 1999) - and a steady influx of tourists, as well as inhabitants of the surrounding region (Leningrad Oblast) who work in the city.

This explains why retail spending per capita is higher then in Russia as a whole and why small business growth has been mainly concentrated in services. Retail trade per capita was $13 \%$ to 50\% higher than the average in Russia between 1995 and 1999 (Goskomstat, 2000), However, the switch of consumers' preference to domestic goods in some sectors, after their initial curiosity for foreign products, helped by the fact that domestic products are improving their 
look, bodes well for industrial entrepreneurs. This tendency has been accelerated by the rouble devaluation.

\section{Conclusion}

When analyzing small business in Russia two factors have to be taken into consideration:

- the limitations of the definition of small business

- the question mark over the reliability of the official statistics.

Official figures are not wholly comparable with those of other European countries because of the different criteria utilised to define small business and therefore tend to belittle small business contribution in Russia. Officially small business in Russia has stagnated after a few years of swift development in the early 1990s, remaining at a level which is well below that in developed market economies and also in the leading transition countries. Small business in Russia has expanded considerably only in Moscow and St. Petersburg. However, data on the total number of enterprises suggest a marked dynamism even in the second half of the nineties. The strong increase of this figure is officially due to the fact that many firms which cease activity are not liquidated and therefore are kept in the state register, while others never become operational. However, the evidence of the survey conducted by Clarke and Kabalina seems to suggest that small business growth has been under-estimated.

The unreliability of statistics is called into question also regarding St. Petersburg. The phenomenal growth that St. Petersburg has experienced in the 1990s might have been partly the consequence of the understatement of the figures in the early 1990s. In St. Petersburg a clear commitment from the local administration to promote small business has been absent. So far it has done very little to support this sector, merely approving mandatory federal legislation and programs for small business support which have, however, remained largely unimplemented. Neither can small business growth be ascribed to the greater concentration of wealth as in Moscow since income levels in St. Petersburg are closer to the Russian average. It is, however, an open question whether income levels in St. Petersburg reflect reality. Apart from this, some other factors can be detected which might plausibly explain the entrepreneurial 
boom in the city. The higher levels of educational attainment and the more "Western mentality" make the citizens of St. Petersburg more prone to engage in entrepreneurial activity. In addition, numerous factors (the presence of a relatively large middle class - by Russian standards - a comparatively large foreign community and the tourist industry) make retail spending per capita in St. Petersburg higher than in Russia as a whole. 


\section{REFERENCES:}

Ageev,A., Gratchev,M.V. and Hisrich,R.D. (1995) Entrepreneurship in the Soviet Union and post-Socialist Russia. Small Business Economics, (7): 365-376.

Alimova, T. and Ermilova,G.(2000) Maloe Predprinimatel'stvo Rossii. Analiz Tekushchego Sostoianiia [Online]. Available: http://docs.rcsme.ru/rus/RC/Analis_MP/default.htm

Avilova,A.V. and others (1997) Financial and institutional problems of the Russian small business (regional aspects) (1995-1997). Moscow.

Babaeva,L.V. and Lapina,G.P. (1997) Malyi biznes v Rossii v epokhu ekonomicheskikh reform. Moscow: Russian Academy of Science.

Bartlett,W. and Prasnikar,J. (1995) Small firms and economic transformation in Slovenia. Communist Economies \& Economic Transformation, 7(1):83-103.

Belenkova,E. (1999) Predprinimatel' zagnan v ugol. Sankt-Peterburburgskie Vedomosti, 11 May, p.2.

Blinov, A.O. (1996) Small business in the modern model of Russia's marketlike economic management. Studies on Russian Economic Development, 7(1): 39-44.

Blinov,A.O. (1998) Maloe predprinimatel'stvo. Moscow: Ocb-89.

BOFIT (2000) Russian \& Baltic economies. The week in Review, May 12, no. 19.

Bohata,M. and Mladek,J. (1998) Development of the SME sector in the Czech Republic. In The Hungarian SME sector development in comparative perspective, edited by L. Csaba. Budapest: Kopint Dator, pp. 145-168.

Borish,M. and Noel,M.(1996) Ahead - and still gaining? Where the private sector stands..... Moct-Most, 6 (2): 25-57.

Brunner,H-P. (1993) Entrepreneurship in Eastern Europe: neither magic nor mirage. A preliminary investigation. Journal of Economic Issues, June, 27(2): 505-513.

Business Eastern Europe, London (1996) Sticky fingers. 25(40):1.

Chepurenko, A.Y., Avilova, A.V. and Pripisnov, V.A.(1995) Maloe predprinimatel'stvo v Rossii: tendentsii razvitiia. In Maloe predprinimatel'stvo v kontekste Rossiiskikh reform $i$ mirovogo opyta, edited by the Russian Indipendent Institute of Social and Nationalities Problems. Moscow: Infomart, pp. 5-39. 
City of St. Petersburg 1996, St. Petersburg (1997) published by the Leontief Centre (St. Petersburg).

Clarke,S. and Kabalina,V. (1999) Employment in the new private sector in Russia. PostCommunist Economies, 11(4): 421-443.

Deikin, A. (1998) Ekonomicheskii spad v malom predprinimatel'stve zamedliaetsia. Finasovye Izvestiia, 23 April, p.II.

Dertouzos, M.L., Lester, R. and Solow, R. (1989) Made in America: Regaining the Productive Edge. Cambridge, Mass.: MIT Press.

EBRD (European Bank for Reconstruction and Development) (1997) Transition report 1997. London: European Bank for Reconstruction and Development.

EBRD (European Bank for Reconstruction and Development) (1998) Transition report 1998. London: European Bank for Reconstruction and Development.

Economist Intelligence Unit (1999) EIU Business Operations Report. $1^{\text {st }}$ quarter 1999.

Fothergill, S. and Gudgin, G. (1982) Unequal Growth: Urban and Regional Employment Change in the UK. London: Heinemann.

Goskomstat Rossii (1996) Russia in figures 1996. Moscow, Goskomstat Rossii, p.226.

Goskomstat Rossii (1998) Rossiiskii Statisticheskii Ezhegodnik 1998. Moscow, Goskomstat Rossii, p. 342.

Goskomstat Rossii (1999) Rossiiskii Statisticheskii Ezhegodnik 1999. Moscow, Goskomstat Rossii, pp. 143, 440.

Goskomstat Rossii (2000) Rossiiskii Statisticheskii Ezhegodnik 2000. Moscow, Goskomstat Rossii, pp. 106, 107, 285, 450.

Goskomstat Rossii: St. Petersburg Committee of State Statistics: various editions of Sozial'noekonomicheskoe polozhenie Sankt-Peterburga i Leningradskoi oblasti. St. Petersburg.

Holtmann,M. (1997) Microcrediting program of the European Bank for Reconstruction and Development. In Microfinance in Russia, edited by the Institute for Private Sector Development and Strategic Analysis. Moscow, pp. 6-8.

IPSSA (Institute for Private Sector Development and Strategic Analysis) (1997) Sistema statisticheskogo nabliudeniia za razvitiem chastnogo sektora. Moscow.

IPSSA (Institute for Private Sector Development and Strategic Analysis) (1998) Small business in Russia. Moscow: Conseco. 
Kuczi,T. and Lengyei,G. (1995) The spread of entrepreneurship in Eastern Europe: survey evidence on entrepreneurial inclination. Budapest: Budapest University of Economic Science.

Kuznetsov,A. McDonald, F., Kuznetsova,O. (2000) Entrepreneurial qualities: a case from Russia. Journal of Small Business Management, 38(1):101-107.

Leontief Center (1998) Podderzhka malogo i srednego biznesa v Sankt-Peterburge. No. 1. St. Petersburg.

Leontief Center (1999) Podderzhka malogo i srednego biznesa v Sankt-Peterburge. No. 2. St. Petersburg.

Lesage, K. and Bayou C.(1993) Saint-Petersbourg: situation economique et presence francaise. Le Courrier des Pays de l'Est 2 (384): 29-46.

Meth-Cohn,D.(1999) Shifting gear. Business Central Europe, May 1999, pp. 14-19.

Milanovic,B. (1998) Distribution and growth. Economic Systems, 22(1): 71-73.

Neace, M.B (1999) Entrepreneurs in emerging economies: creating trust, social capital and civil society. Annals, AAPSS, 565, September 1999: 148-161.

Nelson, L.D. and Kuzes,I.Y. (1995) Privatisation and the new business class. In Russia in transition: politics, privatisation and inequality, edited by D.Lane. London and New York: Longman, pp.119-141.

OECD (Organisation for Economic Co-operation and Development) (1996) SMEs: employment, innovation and growth: the Washington workshop. Paris: OECD.

OECD (Organisation for Economic Co-operation and Development) (1997) OECD economic survey: Russian Federation 1997. Paris: OECD.

OECD (2000) OECD Small and Medium Enterprise Outlook. Paris: OECD.

Olson,M.(1982) The rise and decline of nations; economic growth, stagflation and social rigidities. New Haven and London: Yale University Press.

Pimoshenko, IU.P (1996) Nekotorye Aktual'nye Problemy Nakanune 1 S'ezda Predstavitelei Malogo Predprinimatel'stva. In Finansovye $i$ Institutsional'nye Problemy Rossiiskogo Malogo Predprinimatel'stva (Regional'nye Aspekty), edited by the Russian Indipendent Institute of Social and Nationalities Problems. Moscow: Infomart, pp. 52-55.

Polonsky,G.(1998) Small business in the Russian provinces: case study evidence from Volgograd. Communist Economies \& Economic Transformation, 10(4): 519-537. 
Porter.M.(1990) The competitive advantage of nations. New York: Macmillan.

Predprinimatel' Peterburga (1997) Rezoliutsiia II S'ezda malykh predpriiatii i predprinimatelei Sankt-Peterburga. (23): 5.

Predprinimatel' Peterburga (1999) Fondu dali eshche odin mesiats. (13): 3.

Radaev,V.(1993) Emerging Russian entrepreneurs: as viewed by the experts. Economic and Industrial Democracy, 14(4): 55-77.

Radaev,V. and others (1995) Stanovlenie novogo Rossiiskogo preprinimatel'stva kak issledovatel'skaia problem. In Maloe predprinimatel'stvo v kontekste Rossiiskikh reform $i$ mirovogo opyta, edited by Russian Indipendent Institute of Social and Nationalities Problems. Moscow: Infomart, pp.40-81.

Radaev,V.(1997) Entrepreneurship in Tomsk region: the state of small business. Paper presented at the experts meeting: regional approach to industrial restructuring in Tomsk region held in Tomsk on 3-5 June 1997.

Russian Economic Trends (1996) no.3.

Russian Economic Trends (1997) October monthly update.

Russian Economic Trends (1998) no.1.

Russian Economic Trends (1999) no. 1; no. 2; May monthly update.

Russian Economic Trends (2000) no.4.

Russian SME Resource Centre (1998) Classification of small enterprises by forms of ownership [Online]. Chapter 3 of Statistical analysis of development and efficiency of small business as a sector of the Russian economy, Available: http:/www.rcsme.ru/eng/ Reports/Statistics-RF-SME-Jun98/Part-3.htm

Russian SME Resource Centre (2000) Spravka o sostoianii malogo predprinimatel'stva v Sankt-Peterburge v 1992-1999 godakh [Online]. Available: http://docs.rcsme.ru/rus/Region/St.-Petersburg/SPRAVKA99.DOC

Schleifer,A.(1997) Government in transition. Harvard Institute for International Development, Development Discussion Paper no. 573.

Sergachev,V.(1996) Programma stabilizatsii dlia Peterburga. Ekonomika i Zhizn': Sankt Peterburgskii Regional'nyi Vypusk, 7 December, p.8. 
Shabalina,L.(1999) Fond malogo biznesa stal neupravliaemym. Ekonomika i Vremia: Sankt Peterburgskii Regional'nyi Vypusk, 18 October, p.5.

Shcherbakova, A.(1999) Survey bodes well for local products. The St. Petersburg Times, 8 June, p. 9.

Shiller,R., Boycko,M. and Korobov,V. (1991) Popular attitudes toward free markets: the Soviet Union and the United States compared. American Economic Review, (81): 385-400.

Smallbone, D. and others (1997) Problems Facing the Development of Small and MediumSized Manufacturing Firms in the Baltic States. In Transition in the Baltic States: Microlevel Studies, edited by N. Hood, R. Kilis and J.-E. Vahlne. New York: St. Martin's Press, pp. 227-247.

Sokolovskaia, M. (1998) Fond podderzhki malogo predprinimatel'stva vozvrashchaet rastrachennye den'gi. Finansovye Izvestiia, 30 June, p. VI.

Statisticheskoe Obozrenie (1999) no. 3.

St. Petersburg City Administration (no date) Investor's handbook 2000. Available: http://www.abic.spb.ru/eindex.htm click on industry.

The Delegation of Hungary (1996) Financing small and medium-sized enterprises in Hungary. In Systems for financing newly emerging private enterprises in transition economies, edited by the OECD. Paris.

The Socio-Economic Situation in St. Petersburg. A General Overview, St. Petersburg (1998) no.32.

Vasil'chuk, E.(1997) Malomu biznesu stanovitsia khuzhe, chem vsei ekonomike. Finasovye Izvestiia, 3 June, p.II.

Voprosy Statistiki (1995) Malyi biznes Rossii: adaptatsia k perekhodnym usloviiam. (9): 1968.

Webster, L.M. and Charap, J. (1993) The emergence of private sector manufacturing in St. Petersburg. A survey of firms. Washington: The World Bank.

Zhuravskaya, E. (1998) Why regulation matters for private protection rackets and public goods provision. Russian Economic Trends, 7(4): 54-58.

INTERVIEWS WERE HELD WITH:

Tatiana Alimova, leading expert of the Russian SME Resource Centre. 
Natalia Bagrova, vice-director of the Department for the Development of Entrepreneurship of the Administration of the Leningrad Region.

Aleksandr Barbanel, general director of Garant (a law firm).

Elena Belova, expert of the Leontief Center.

Jury Blinov, general director of the Association for the Promotion of Innovation Activity in St. Petersburg.

Vladimir Buev, expert of the Institute for Private Sector Development and Strategic Analysis.

Kim Carlton, deputy director of the Innovation Centre for the production of clothes.

Elena Danishevskaia, loan co-ordinator of the Center for Citizen Initiatives.

J.A. Duffy, advisor of the Chamber of Commerce and Industry for Amsterdam on assignment in St. Petersburg.

Nikolai Ermilov, general director of ILIP.

Constantin Eskin, deputy director of the Committee for Economy and Industrial Policy of the St. Petersburg administration.

Valentine Galenko, director of the Higher Economics School.

Sergei Gavrilov, chief redactor of Predprinimatel' Peterburga.

Ilya Karasev, vice-president of the U.S.-Russia Investment Fund.

David Kerry, country director of International Executive Service Corps.

Alexander Kizhin, deputy director of organisation at the Higher Economics School.

Larisa Kushnarenko, consultant of the Stockholm School of Economics in Russia.

Igor Lonsky, head of department of the Administration of St. Petersburg-External Affairs Committee.

Oleg Melnikov, vice-director of the technopark of the Technical University in St. Petersburg.

Alexander V. Nekludov, deputy executive of Rusnord. 
Albina Nikkonen, deputy director of the Regional Fund for Scientific and Technological Development.

Yuri Nurulin, director for international relations of the Federal Programme "Engineering Network of Russia".

Thomas Oetter, a consultant working for the EBRD Small Business Fund.

Andrei Orlov, deputy chairman of the State Committee for the Support and the Promotion of Entrepreneurship.

Roman Pastukhov, president of the Union of Entrepreneurs of St. Petersburg.

Constantin Pechatnikov, director of Business Development Center of the Vyborgskii district.

Vera Popova, director of the Innovation Center of the Technical University in St. Petersburg.

Boris Salov and Boris Novikov, main redactor and general director of Innovatsii - scientific magazine.

Lev Savulkin, senior researcher of the Leontief Center.

Olga Seliuk, expert of the Institute of Social and Economic Problems of the Russian Academy of Science.

Sergei Siling, general director of the Fund for the Development of Science, Technology and Franchising.

Vladimir Spivak, director of the Svetlana Innovation Center.

Charles Towers-Clerk, BESO (British Executive Service Overseas) consultant on assignment in a Russian bank.

Joseph Tukkel, director of Institute of Innovation of the Technical University in St. Petersburg.

Vladimir Tul'vert, "main specialist" of the Innovation-Marketing Centre of the State Fund for the Development of Small Business in St. Petersburg.

Vladlena V. Yeliseeva, chief expert of the SME Development Department of the Committee for Economy and Industrial Policy Administration of St. Petersburg.

Vera Yuzkova, deputy director of Business Collaboration Center. 
Igor Zaitsev, assistant of the vice-director of the technopark of the Technical University in St. Petersburg.

T. B., general director of Fitolon.

E. C., general director of Melp.

S. H., general manager of Slavia.

O. L., general director of Acvasviaz.

M. M., general director of Gefest.

T. P., director of BMN Peterburg.

E. R., chief accountant of R. 


\section{William Davidson Institute Working Paper 439}

TABLE 1.

Number of small businesses and total number of firms in Russia

\begin{tabular}{|c|c|c|c|c|c|c|c|c|c|}
\hline & 1991 & 1992 & 1993 & 1994 & 1995 & 1996 & 1997 & 1998 & 1999 \\
\hline $\begin{array}{l}\text { (A) Small } \\
\text { businesses }\end{array}$ & 266.7 & 560.0 & 5.0 & 896.9 & 877.3 & 841.7 & 861.1 & 868.0 & 890.6 \\
\hline of firn & 314.2 & 609.0 & $1,244.9$ & 946.3 & $2,249.5$ & $2,504.5$ & $2,727.1$ & $2,901.2$ & $3,081.6$ \\
\hline$\%$ of $A$ to $B$ & 84.9 & 92.0 & 69.5 & 46.1 & 39.0 & 33.8 & 31.6 & 29.9 & 28.9 \\
\hline
\end{tabular}

The figures are listed in thousands and refer to the end of each year.

Sources: Goskomstat, 1998: 342; Statisticheskoe Obozrenie, 1999, no. 3: 19; Goskomstat, 1996: 226; Goskomstat, 1999: 274, 281; Alimova and Ermilova, 2000.

TABLE 2

Number of small businesses in St. Petersburg

\begin{tabular}{|cccccccc|}
$\mathbf{1 9 9 2}$ & $\mathbf{1 9 9 3}$ & $\mathbf{1 9 9 4}$ & $\mathbf{1 9 9 5}$ & $\mathbf{1 9 9 6}$ & $\mathbf{1 9 9 7}$ & $\mathbf{1 9 9 8}$ & $\mathbf{1 9 9 9}$ \\
9,697 & 22,695 & 57,072 & 68,379 & 88,238 & 101,455 & 111,800 & 109,700 \\
\hline
\end{tabular}

Sources: Goskomstat Rossii: St. Petersburg Committee of State Statistics: various editions of Sozial'no-

ekonomicheskoe polozhenie Sankt-Peterburga i Leningradskoi oblasti 


\section{William Davidson Institute Working Paper 439}

TABLE 3

Number of small businesses in St. Petersburg divided by sector

\begin{tabular}{|l|r|r|r|r|r|r|r|r|r|}
\hline Economic branches: & $\mathbf{3 0 / 0 6 / 9 2}$ & $\mathbf{3 1 / 1 2 / 9 2}$ & $\mathbf{3 1 / 1 2 / 9 3}$ & $\mathbf{3 1 / 1 2 / 9 4}$ & $\mathbf{3 1 / 1 2 / 9 5}$ & $\mathbf{3 1 / 1 2 / 9 6}$ & $\mathbf{3 1 / 1 2 / 9 7}$ & $\mathbf{3 1 / 1 2 / 9 8}$ & $\begin{array}{c}\text { increase } \\
\mathbf{9 8 / 9 2}\end{array}$ \\
\hline Industry & 1,407 & 1,933 & 5,384 & 11,736 & 10,068 & 14,218 & 16,757 & 19,453 & $906 \%$ \\
\hline Agriculture & & & & 46 & 65 & 281 & 366 & & \\
\hline Transport and communication & 110 & 139 & 523 & 1,606 & 1,801 & 2,128 & 2,571 & 3,689 & $3254 \%$ \\
\hline Construction & 1,190 & 1,655 & 4,662 & 10,601 & 9,695 & 13,384 & 14,160 & 17,441 & $1366 \%$ \\
\hline Retail trade and public catering & 846 & 1,827 & 5,436 & 18,176 & 28,558 & 36,745 & 44,775 & 52,546 & $6111 \%$ \\
\hline Material supplies and sales & & & & 967 & 924 & 806 & 936 & & \\
\hline Information services & 15 & 119 & 283 & 190 & 254 & 402 & 532 & 447 & $2881 \%$ \\
\hline Real estate transactions & & & & 99 & 256 & 659 & 854 & & \\
\hline $\begin{array}{l}\text { General comm. activity to } \\
\text { support market functioning }\end{array}$ & 324 & & 682 & 2,027 & 3,016 & 3,011 & 3,651 & 3,130 & $866 \%$ \\
\hline $\begin{array}{l}\text { Other kinds of activity in the } \\
\text { sphere of material production }\end{array}$ & & 411 & 208 & 521 & 590 & 724 & 2,929 & & \\
\hline $\begin{array}{l}\text { Housing and public utilities; non } \\
\text { production services rendered to } \\
\text { households }\end{array}$ & 237 & & & & 585 & 220 & & 1,789 & $655 \%$ \\
\hline $\begin{array}{l}\text { Health care, physical culture } \\
\text { and sport, social security }\end{array}$ & 197 & 307 & 581 & 1,778 & 2,162 & 1,450 & 2,937 & 2,795 & $1319 \%$ \\
\hline Education & 82 & 144 & 274 & 751 & 880 & 802 & 1,104 & 671 & $718 \%$ \\
\hline Culture and art & 84 & 125 & 256 & 768 & 1,004 & 1,068 & 1,416 & 1,230 & $1364 \%$ \\
\hline Science and scientific services & 1,257 & 1,803 & 3,248 & 5,810 & 6,879 & 6,631 & 6,513 & 3,242 & $158 \%$ \\
\hline $\begin{array}{l}\text { Finance, credit, insurance, } \\
\text { pension security }\end{array}$ & & & & & 805 & 1,250 & & & \\
\hline Other sectors & 348 & 1,234 & 1,158 & 1,996 & 837 & 4,459 & 1,954 & 5,366 & $1442 \%$ \\
\hline Total & $\mathbf{6 , 0 9 7}$ & $\mathbf{9 , 6 9 7}$ & $\mathbf{2 2 , 6 9 5}$ & $\mathbf{5 7 , 0 7 2}$ & $\mathbf{6 8 , 3 7 9}$ & $\mathbf{8 8 , 2 3 8}$ & $\mathbf{1 0 1 , 4 5 5}$ & $\mathbf{1 1 1 , 8 0 0}$ & $\mathbf{1 7 3 4 \%}$ \\
\hline
\end{tabular}

Nota bene: data for some economic branches are not available for every single year

Sources: Goskomstat Rossii: St. Petersburg Committee of State Statistics: various editions of Sozial'noekonomicheskoe polozhenie Sankt-Peterburga i Leningradskoi oblasti 


\section{William Davidson Institute Working Paper 439}

TABLE 4

Trends in industrial production in Russia and St. Petersburg

\begin{tabular}{|lccccccccc|}
\hline & $\mathbf{1 9 9 1}$ & $\mathbf{1 9 9 2}$ & $\mathbf{1 9 9 3}$ & $\mathbf{1 9 9 4}$ & $\mathbf{1 9 9 5}$ & $\mathbf{1 9 9 6}$ & $\mathbf{1 9 9 7}$ & $\mathbf{1 9 9 8}$ & $\mathbf{1 9 9 9}$ \\
RUSSIA & $-8 \%$ & - & - & $-22.8 \%$ & - & $-4.0 \%$ & $+1.9 \%$ & $-5.2 \%$ & $+8.1 \%$ \\
ST. PETERSBURG & & $18.8 \%$ & $16.2 \%$ & & $4.7 \%$ & & & & \\
& & - & - & $-36.1 \%$ & - & $-20.5 \%$ & $+9 \%$ & $-0.3 \%$ & $+7.8 \%$ \\
\hline
\end{tabular}

Sources: Russian Economic Trends, 1996, no. 3: 138; Russian Economic Trends, 1999, no. 2: 101-102; Russian Economic Trends, 2000, no. 4: 70; Goskomstat, 1999: 300; St. Petersburg City Administration (no date); Goskomstat Rossii: St. Petersburg Committee of State Statistics: various editions of Sozial'no-ekonomicheskoe polozhenie Sankt-Peterburga i Leningradskoi oblasti

TABLE 5

Share of imports in overall retail trade

\begin{tabular}{|lcccccccccc|}
\hline & $\mathbf{1 9 9 1}$ & $\mathbf{1 9 9 2}$ & $\mathbf{1 9 9 3}$ & $\mathbf{1 9 9 4}$ & $\mathbf{1 9 9 5}$ & $\mathbf{1 9 9 6}$ & $\mathbf{1 9 9 7}$ & $\mathbf{1 9 9 8}$ & $\mathbf{1 9 9 9}$ & $\mathbf{2 0 0 0}$ \\
Domestic & 86 & 77 & 71 & 52 & 46 & 48 & 51 & 57 & 70 & 66 \\
Imported & 14 & 23 & 29 & 48 & 54 & 52 & 49 & 43 & 30 & 34 \\
\hline
\end{tabular}

Source: Russian Economic Trends, 2000, n. 4: 73. 


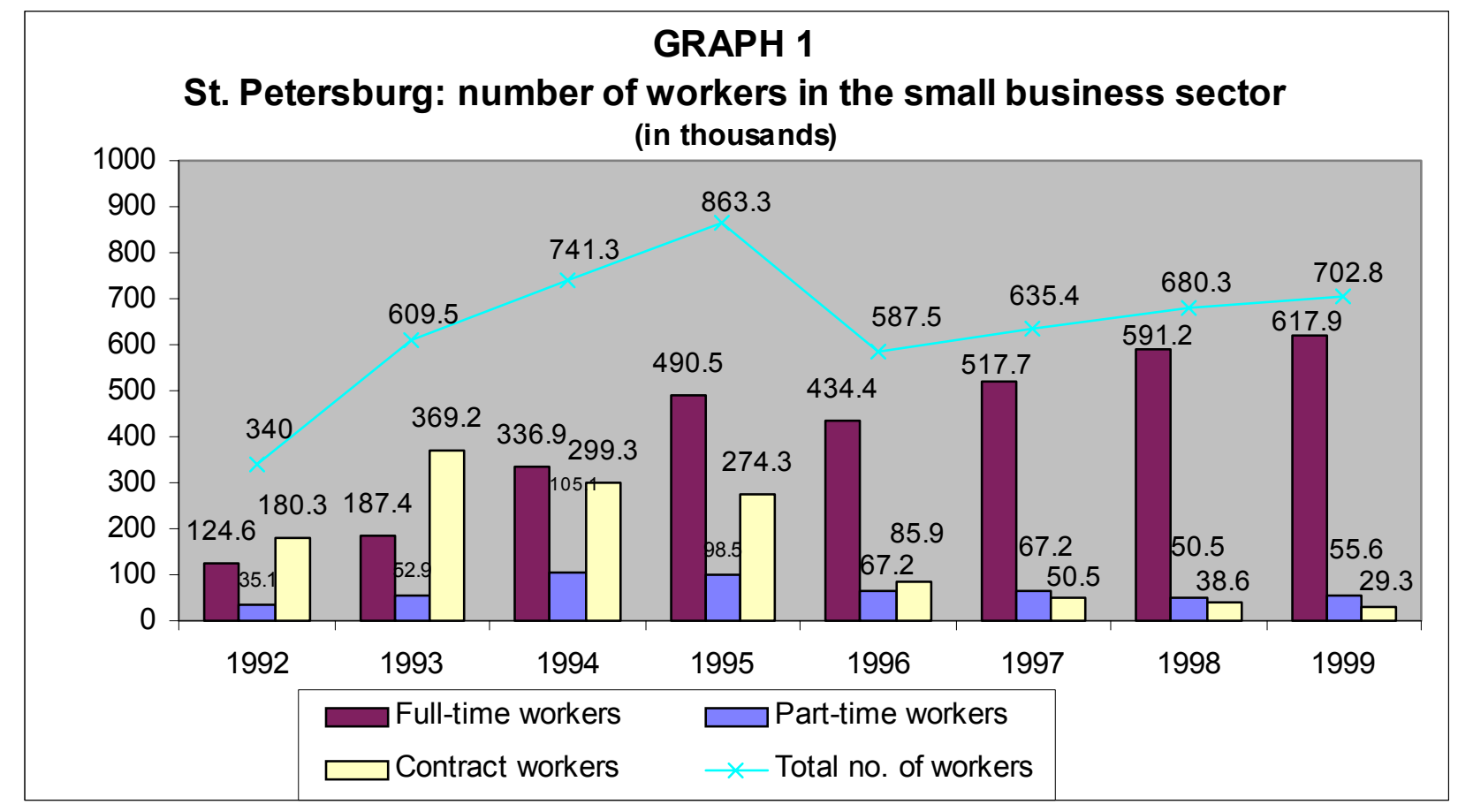

Nota bene: the decrease in 1996 is to be attributed to the change in the criteria used to define small business Sources: Goskomstat Rossii: St. Petersburg Committee of State Statistics: various editions of Sozial'noekonomicheskoe polozhenie Sankt-Peterburga i Leningradskoi oblasti 


\section{DAVIDSON INSTITUTE WORKING PAPER SERIES - Most Recent Papers}

The entire Working Paper Series may be downloaded free of charge at: www.wdi.bus.umich.edu

CURRENT AS OF 3/12/02

\begin{tabular}{|c|c|c|}
\hline Publication & Authors & Date \\
\hline No. 439: Small business in Russia: A Case Study of St. Petersburg & Alessandro Kihlgren & Jan. 2002 \\
\hline $\begin{array}{l}\text { No. 438: Foreign Direct Investment as Technology Transferred: } \\
\text { Some Panel Evidence from the Transition Economies }\end{array}$ & $\begin{array}{l}\text { Nauro F. Campos and Yuko } \\
\text { Kinoshita }\end{array}$ & Jan. 2002 \\
\hline No. 437: Whistleblowing, MNC's and Peace & Terry Morehead Dworkin & Feb. 2002 \\
\hline $\begin{array}{l}\text { No. 436: A Note on Measuring the Unofficial Economy in the Former } \\
\text { Soviet Republics }\end{array}$ & $\begin{array}{l}\text { Michael Alexeev and William } \\
\text { Pyle }\end{array}$ & Sept. 2001 \\
\hline $\begin{array}{l}\text { No. 435: The Ownership School vs. the Management School of State } \\
\text { Enterprise Reform: Evidence from China }\end{array}$ & David D. Li and Changqi Wu & Jan. 2002 \\
\hline $\begin{array}{l}\text { No. 434 Forthcoming in: The Journal of Economic Perspectives, "The } \\
\text { Effect of Ownership and Competitive Pressure on Firm Performance in } \\
\text { Transition Countries: Micro Evidence from Bulgaria, Romania and } \\
\text { Poland," 16(2) Feb. 2002. }\end{array}$ & $\begin{array}{l}\text { Manuela Angelucci, Saul Estrin, } \\
\text { Jozef Konings, and Zbigniew } \\
\text { Zolkiewski }\end{array}$ & Jan. 2002 \\
\hline No. 433: The End of Moderate Inflation in Three Transition Economies? & Josef C. Brada and Ali M. Kutan & Jan. 2002 \\
\hline $\begin{array}{l}\text { No. 432: What Drives the Speed of Job Reallocation During Episodes of } \\
\text { Massive Adjustment? }\end{array}$ & $\begin{array}{l}\text { Stepan Jurajda and Katherine } \\
\text { Terrell }\end{array}$ & Jan. 2002 \\
\hline No. 431: Competition and Corporate Governance in Transition & Saul Estrin & Dec. 2001 \\
\hline $\begin{array}{l}\text { No. 430: Corporate Governance in the Cause of Peace: An } \\
\text { Environmental Perspective }\end{array}$ & Don Mayer & Jan. 2002 \\
\hline No. 429: Why do Governments Privatize? & $\begin{array}{l}\text { Loren Brandt, Hongbin Li, and } \\
\text { Joanne Roberts }\end{array}$ & Dec. 2001 \\
\hline No. 428: Testing Russia's Virtual Economy & Vlad Ivanenko & Dec. 2001 \\
\hline No. 427: War and the Business Corporation & Eric W. Orts & Dec. 2001 \\
\hline $\begin{array}{l}\text { No. 426: Partial Privatization and Firm Performance: Evidence from } \\
\text { India }\end{array}$ & Nandini Gupta & Dec. 2001 \\
\hline $\begin{array}{l}\text { No. 425: Direct Foreign Investments and Productivity Growth in } \\
\text { Hungarian Firms, 1992-1999 }\end{array}$ & Jérôme Sgard & Nov. 2001 \\
\hline $\begin{array}{l}\text { No. 424: Banking Passivity and Regulatory Failure in Emerging } \\
\text { Markets: Theory and Evidence from the Czech republic. }\end{array}$ & Jan Hanousek and Ger & July 2001 \\
\hline $\begin{array}{l}\text { No. 423: Conceptions of the Corporation and the Prospects of } \\
\text { Sustainable Peace }\end{array}$ & Jeffrey Nesteruk & 2001 \\
\hline No. 422: The Role of the Corporation in Fostering Sustainable Peace & Timothy Fort and Cindy Schipani & Nov. 2001 \\
\hline No. 421: Wage Arrears and the Distribution of Earnings in Russia & $\begin{array}{l}\text { Hartmut Lehmann and Jonathan } \\
\text { Wadsworth }\end{array}$ & Dec. 2001 \\
\hline $\begin{array}{l}\text { No. 420: Transferring Collective Knowledge: Collective and } \\
\text { Fragmented Teaching and Learning in the Chinese Auto Industry }\end{array}$ & $\begin{array}{l}\text { Jane Zhou, Jaideep Anand, and } \\
\text { Will Mitchell }\end{array}$ & Dec. 2001 \\
\hline $\begin{array}{l}\text { No. 419: Liberalization, Corporate Governance, and the Performance of } \\
\text { Newly Privatized Firms }\end{array}$ & $\begin{array}{l}\text { Narjess Boubakri, Jean-Claude } \\
\text { Cosset, and Omrane Guedhami }\end{array}$ & Dec. 2001 \\
\hline $\begin{array}{l}\text { No. 418: The European Data Privacy Directive and International } \\
\text { Relations }\end{array}$ & Steven R. Salbu & Dec. 2001 \\
\hline $\begin{array}{l}\text { No. 417: Capital Markets and Capital Allocation: Implications for } \\
\text { Economies in Transition }\end{array}$ & $\begin{array}{l}\text { Artyom Durnev, Randall Morck, } \\
\text { and Bernard Yeung }\end{array}$ & Dec. 2001 \\
\hline $\begin{array}{l}\text { No. 416: Forthcoming in: The Journal of Economic Perspectives, "Data } \\
\text { Watch. Research Data from Transition Economies," 16(2) Feb. } 2002 .\end{array}$ & $\begin{array}{l}\text { Randall K. Filer and Jan } \\
\text { Hanousek }\end{array}$ & Dec. 2001 \\
\hline $\begin{array}{l}\text { No. 415: Forthcoming in: The Journal of Economic Perspectives, } \\
\text { "Transition Economies: Performance and Challenges," 16(2) Feb. } 2002 .\end{array}$ & Jan Svejnar & Dec. 2001 \\
\hline $\begin{array}{l}\text { No. } 415 \text { Forthcoming in: The Journal of Economic Perspectives, } \\
\text { "Transition Economies: Performance and Challenges," 16(2) Feb. } 2002 .\end{array}$ & Jan Svejnar & Dec. 2001 \\
\hline $\begin{array}{l}\text { No. } 414 \text { Forthcoming in: The Journal of Economic Perspectives, "The } \\
\text { Great Divide and Beyond: Financial Architecture in Transition," 16(2) } \\
\text { Feb. } 2002 .\end{array}$ & Erik Berglof and Patrick Bolton & Dec. 2001 \\
\hline
\end{tabular}

